\title{
Offshore Wind Power for Marine Conservation
}

\author{
Linus Hammar1* ${ }^{*}$, Diana Perry², Martin Gullström² \\ ${ }^{1}$ Department of Energy and Environment, Chalmers University of Technology, Gothenburg, Sweden \\ ${ }^{2}$ Department of Ecology, Environment and Plant Sciences, Stockholm University, Stockholm, Sweden \\ Email: *linus.hammar@chalmers.se
}

Received 30 November 2015; accepted 18 January 2016; published 22 January 2016

Copyright (C) 2016 by authors and Scientific Research Publishing Inc.

This work is licensed under the Creative Commons Attribution International License (CC BY). http://creativecommons.org/licenses/by/4.0/

(c) (i) Open Access

\begin{abstract}
The seas of northern Europe are strongly affected by human activities and there is a great need for improved marine conservation. The same region is also the current hotspot for offshore wind power development. Wind farms can have negative environmental impacts during construction, but during the operational phase many organisms are attracted to the foundations and thereby may also find refuge from fisheries. Given the recent implementation of marine spatial planning in Europe and elsewhere, this is a critical time to address potential compatibility and synergies between marine conservation and wind power. This review concludes that offshore wind farms can be at least as effective as existing marine protected areas in terms of creating refuges for benthic habitats, benthos, fish and marine mammals. The degree of advantage for these organisms depends on the location of the wind farm and the level of imposed fishing restriction. Under certain conditions wind farms may even be more efficient means of conservation than ordinary marine protected areas. However, offshore wind farms can be negative for several species of seabirds, essentially as occupying preferred feeding or wintering grounds. In areas important to these seabirds wind farms may not comply with conservation. The results bring important messages to marine spatial planning as some but not all wind farms can be spatially combined with, and even synergistic to, marine conservation.
\end{abstract}

\section{Keywords}

Marine Conservation, Offshore Wind Power, Marine Spatial Planning, Marine Management

\section{Introduction}

Human pressures have resulted in biodiversity loss and structural changes in marine ecosystems on local and global scales, with the seas of northern Europe being among the most affected [1] [2]. This has created a need 
for marine conservation efforts, and during the last decade the use of ecosystem-based spatial approaches has conspicuously accelerated. Marine conservation areas, often referred to as marine protected areas (MPAs), imply that human activities are restricted within designated areas in order to create safe havens for valuable populations or ecosystems. The level of regulation varies among different MPAs and strongest protection is typical where fishing is restricted or prohibited (marine reserves) [3]. Conservation areas can be very large and rigorous in countries with large offshore territories, such as the United States and Australia, but this has rarely been possible along the densely populated coasts of Europe. Instead, the European Union has implemented the patchwork of Natura 2000 areas with many small MPAs of various levels of protection [4]. However, even small MPAs can be of critical importance as refuges and for maintaining ecological connectivity in coastal waters [5].

Today marine management often involves ecosystem-based marine spatial planning (MSP) [6] [7], which serves to support sustainable, efficient and predictable use of marine resources. But this long-term political planning can also create competition for space among sectors and stakeholder interests. European goals for marine conservation imply a significant increase in protected areas [3] and the possibility for spatial overlaps, i.e. compatibility, between conservation and economic sectors becomes important to consider.

Following regional resolutions [6] [8], both marine spatial planning and enhancement of MPAs are under development in the heavily deprived North Sea and Baltic Sea. The same region is also the current hotspot for offshore wind power [9] and large developments are included in the MSP agenda for most of the concerned countries. The impacts of offshore wind power on marine ecosystems are not known for all taxa and all ecosystems, but much data have been recorded over the last decade and general impacts can be outlined, particularly for northern European waters [10]. For instance, it is evident that the construction work can cause significant damage to marine life if appropriate mitigation measures are not undertaken [11]. But during the operational phase environmental impacts are not necessarily of detrimental nature; fishing pressure ceases and many organisms take advantage of the new installations [12] [13].

If conditions for threatened populations or valuable biodiversity rich ecosystems are more viable in offshore wind farms than in surrounding areas, wind farms may, in practice, function as marine conservation areas. Since ecosystem-based MSP requires a balancing of stakeholder uses, with as few spatial restrictions as possible yet without endangering local ecosystems, ways of simultaneously planning for economic development and conservation at the same location would be valuable management options.

In this review, we examine the hypothesis that operational offshore wind farms function directly and/or indirectly in favor of marine conservation, based on findings from wind power monitoring programs and research from northern Europe (Figure 1).

\section{Marine Life in Offshore Wind Farms}

The aim of conservation is to preserve or enhance pristine ecosystems or promote and provide protection for threatened populations and species [14] [15]. For offshore wind farms to function in favor of marine conservation the long term viability of these ecological entities must be higher inside the wind farm area than outside the area and before the installation. For effective conservation positive effects should also diffuse out to surrounding areas [16].

Wind farms have different effects on different taxa and the potential for conservation benefits are therefore dependent on the specific target for conservation. In this section we review wind farm induced changes to 1) seabed habitats and benthos, 2) epifouling benthos, 3) fish, 4) marine mammals, and 5) seabirds. A brief illustration of offshore wind power is given in Figure 2.

\subsection{Benthic Habitats and Benthos between Offshore Wind Turbines}

Offshore wind farms are almost exclusively installed in sediments of mud, clay, sand or gravel [9] [17] although future projects may take place on rocky seabed [18]. At the time of installation the natural habitat is replaced by hard substrate consisting of foundations and score protection (gravel and boulders). In between the foundations cables are placed interposed or on top of the seabed. This construction work disturbs habitats and benthos [19]. However, once the operational phase begins the impacts from the turbines are more subtle. For instance, changes to seabed coverage were studied before and after the installation of the shallow offshore wind farm "Middelgrunden” in the Öresund strait, Denmark [20]. Prior to installation seagrass meadows (Zostera marina) predo- 


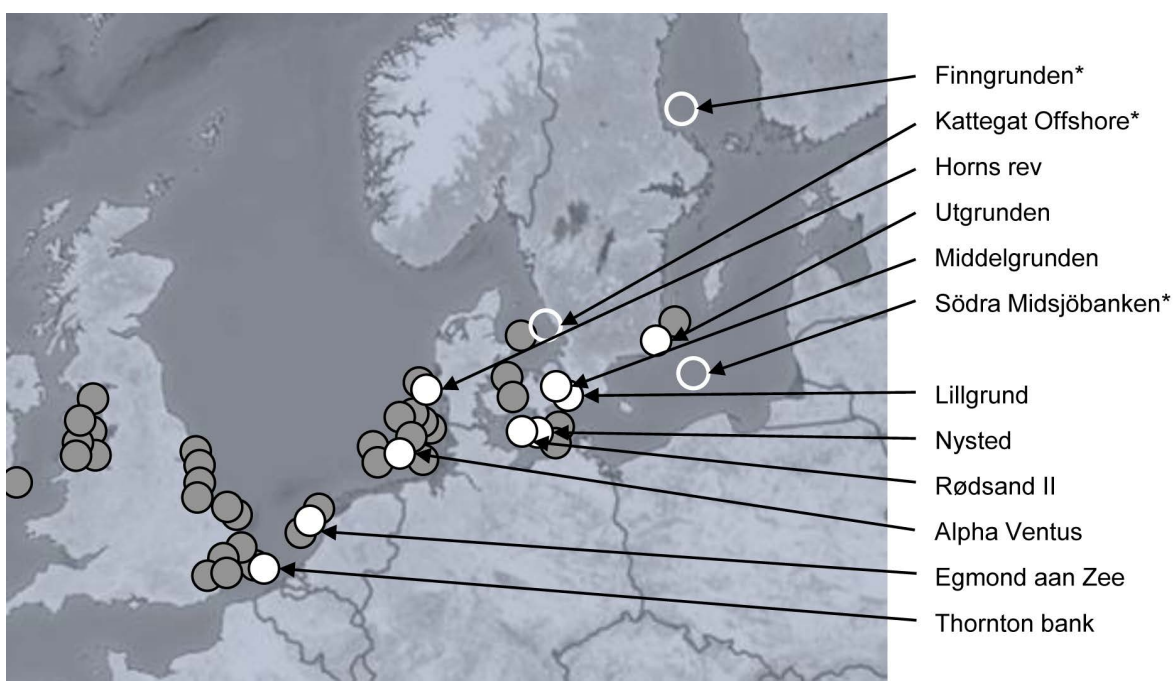

Figure 1. Operating wind farms (2015) in northern Europe. Circles indicate wind farms $>10$ MW at water depth $>2 \mathrm{~m}$ where filled white circles are wind farms referred to in this review. *Open circles indicate planned wind farms referred to in this review. Data from 4C Offshore Database.

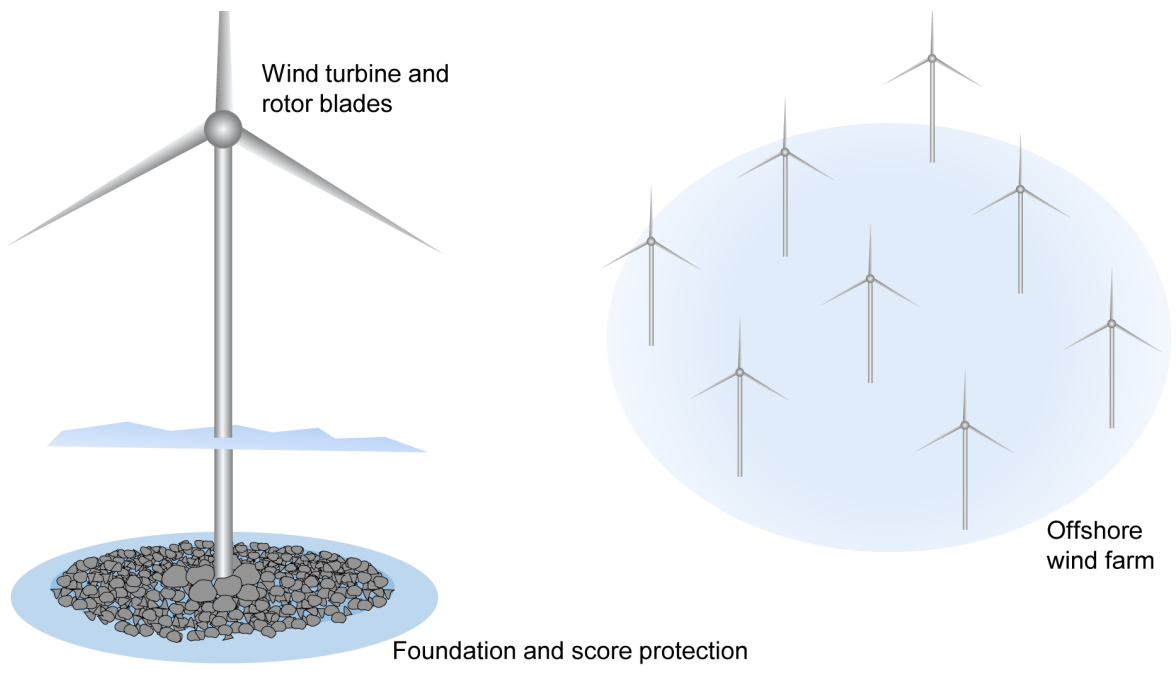

Figure 2. Areas of influence at individual offshore wind turbines (left) and offshore wind farms (right) during the operation phase. Illustrations are not to scale.

minantly covered the coarse sediment seabed, while high abundance of blue mussels (Mytilus edulis) was seen in unvegetated areas. Three years after installation of the wind turbines the seagrass coverage had increased while blue mussel abundance on the seabed had slightly decreased. Five years of seagrass monitoring was also carried out at the offshore wind farm "Lillgrund" located on a shallow vegetated sand bank in the Swedish part of Öresund strait [21]. The quality of seagrass was compared with reference areas in order to identify possible effects of the installation but no effects of the wind farm were detected. Gravity foundations and dredging were used in both these wind farms and the results indicate no negative impact on seagrass vegetation.

Wind power foundations and score protections do not only occupy space but also interrupt water movements such as wave motions and currents. At unvegetated seabeds such hydrodynamic alteration may change the sediment composition (i.e. grain size) given that currents are strong or wave action reaches down to the seabed. This may in turn change the conditions for benthic organisms locally, to the benefit for some species at the cost of others [22]. The turbine structures also attract fish (see Section 2.3) which can change the predation pressure on benthos at the surrounding seabed. While these two effects (sediment alternation and predation pressure) on 
seabed communities are difficult to distinguish, the spatial extent is estimated to $50 \mathrm{~m}$ from the foundations, based on monitoring of infauna assemblages in the Belgian wind farm "Thornton bank" in the North Sea [23].

Based on these findings, the direct impacts on benthic habitats and benthos occur at local scales, within tens of meters from turbine foundations and cables. Benthic fauna diversity is higher where hard substrates are scattered over soft sediment bottoms, as has been shown in Norwegian waters [24]. Wind farms may therefore enhance diversity in areas with homogeneous seabed.

Due to the exclusion or reduction of other activities in the occupied area the indirect effects of a wind farm can be particularly important. With regard to benthic habitats and benthos the possible prohibition of bottom trawling is particularly relevant, as this activity is known as a major threat to marine biodiversity and benthic habitats [25] [26]. Trawling for benthic fish and crustaceans occurs on soft bottom seabeds, typically deeper than $20 \mathrm{~m}$. The trawl boards cut through sediments like a plow and the net scrapes off macro-benthos and any biogenic structure as it swipes over the seabed. Trawling for scallops and other shells typically occurs in shallow sandy areas, with the beam of the trawl or dredge digging deep into the seabed. The loss of benthic animals, particularly filter-feeders, is massive in all areas exposed to bottom trawling [27]. For example, in the North Sea alone thousands of square kilometers of oyster beds have been lost to bottom trawls and scallop dredging [28]. In the Kattegat Sea, previously abundant reefs built by the filter-feeding crustaceans Haploops spp. have become virtually extinct due to bottom trawling [29]. In areas of intense bottom trawling the seabed can be disturbed several times per year, although there are also locations which for various reasons are never exposed [30]. Such areas can function as refuges for sessile benthos. In areas with muddy seabed, these refuges are nevertheless exposed to heavy siltation if trawling takes place in the surroundings [31].

Trawling is not permitted in wind farms. This is because of navigational safety requirements and the risk of damage to cable infrastructure. Hitherto the incompatibility between trawling and offshore wind energy has not led to any major reductions or relocations of trawling because wind farms have been located in areas less important for fisheries. However, if offshore wind power is to expand according to projections [32] [33] and plans [9] some wind farms will inevitably be located in areas previously exposed to bottom trawling. One such example is the "Kattegat Offshore" wind farm recently (2015) permitted in eastern Kattegat at a location periodically exposed to bottom trawl fisheries.

In areas where bottom trawling ceases the benthic fauna recover with time, ranging from months to decades [34]. The installation of a wind farm in waters previously exposed to bottom trawling would imply at least 30 years of protection and could be an important means of conservation.

\subsection{Epifouling Benthos on Offshore Wind Turbine Foundations}

As soon as wind power foundations are installed the colonization of microbes initiates and is quickly followed by larger animals, and to some extent algae [35] [36]. Hard substrates are a scarcity in the marine environment and the succession order of colonizing species depends on a range of factors such as seasonal larvae abundance and shape and material of the foundation [37]. With time, filter-feeding animals tend to dominate the vertical structures while the base of the foundations and the score protections are typically colonized by crabs and starfish [23] [38] [39]. At the German wind farm "Alpha Ventus" a 100 fold higher abundance of epibenthic fauna were found on the foundations compared to surrounding seabed, with several thousand brown crabs (Trachurus trachurus) inhabiting single foundations [40]. It should be noted that Bergmark and Jørgensen [41] found that offshore structures left from oil and gas platforms were, in fact, instrumental in creating new settlement habitats for the vulnerable deep water coral Lophelia pertusa in the North Sea. This observation is of high conservation interest since $L$. pertusa is a threatened species in the North Sea [42] and similar settling opportunities can be expected at offshore wind farms moored at sufficient depth and conditions. The foundations of offshore wind farms create a hard substrate similar to that created by offshore oil rigs.

\subsection{Fish in Offshore Wind Farms}

The foundations and score protections, colonized by epifauna as described above, function as artificial reefs and attract hard substrate associated fish. Many different species of fish have been shown to be attracted to wind power foundations in the North Sea and Baltic Sea. For instance, at the "Lillgrund" wind farm in Öresund strait attraction was shown for Atlantic cod (Gadus morhua), shorthorn sculpin (Myoxocephalus scorpius), goldsinny wrasse (Ctenolabrus rupestris), black goby (Gobius niger), eelpout (Zoarces viviparus) and European eel (An- 
guilla anguilla) [43]. At the Belgian wind farm “Thorntonbank" the attraction of pouting (Trisopterus luscus) was particularly distinct, with mean densities of 14 individuals per square meter above the score protection (i.e. 22,000 individuals per foundation). This pouting density was estimated to be 104 times higher than in surrounding areas. Effects on the important keystone species Atlantic cod, whereof several populations are vulnerable, are of particular interest. For this species attraction to foundations has been shown at several wind farms in northern Europe [39] [43] [44]. Tagging experiments at the Dutch "Egmond aan Zee” wind farm even revealed that some cod took up residence at individual wind power foundations for several months in a row [45].

It is clear that fish attracted to wind power foundations show preference to the provided advantages of food and shelter; however, close to the foundations they are also exposed to low frequency noise from operating turbines. It is not fully understood if this noise exposure has any negative, subtle effects in the longer term [10] [46] as differences have been shown for different species. Experiments have indicated that juvenile European eels suffer from reduced ability to avoid predators in noisy environments [47]. On the contrary, a fitness study on Atlantic cod and pouting caught at wind power foundations did not reveal any differences in condition compared to specimens caught in reference areas [48].

It has been questioned whether attraction to foundations, or wind farms as a whole, is beneficial for fish and leads to enhanced fish production supporting conservation, or if this behavioral pattern can be an ecological trap where fish are misled to stay in disadvantageous areas. It is possible that the answer to this question is case dependent, since the gathering of fish at specific locations can facilitate predation [49] and fishing near the perimeter of the farms [13]. However, based on monitoring of gadoid fish at Belgian wind farms there are no indications of the hypothesized ecological trap theory and wind farms can rather be regarded as areas of opportunity for these fish [13]. As in the case of MPAs, a potential spillover effect can be seen as a desirable outcome of conservation for surrounding fisheries [14].

The spatial extent of this aforementioned attraction of fish is variable and not well established. However, monitoring programs from wind farms have indicated that the abundance of several species increases not only in the vicinity of foundations, as noted above, but also in the area in between turbines, compared to controls [50].

In addition to the food and shelter advantages of wind power foundations the indirect impacts of excluding other human activities can be highly beneficial to fish—both around the turbine foundations and in the surrounding areas inside the wind farm. Obviously fishing, and trawl fishing in particular, has fundamental effects on fish populations [51] [52] and their life stage structures [1]. For instance, the British fishing fleet is estimated to have reduced the landings per effort by $94 \%$ over the last century, indicating the enormous impact of fishing on stocks. Given the fishing pressure in most parts of northern Europe only stationary and semi-stationary fish are likely to benefit substantially from the shelter of wind farms although this question may only be resolved with time. Many species migrate and seek out particular areas for spawning, thus reducing the population level advantages of local protected areas, as has been indicated for Atlantic cod in North Sea wind farms [48].

\subsection{Marine Mammals in Offshore Wind Farms}

Marine mammals avoid, and can even be harmed by, wind power construction work, particularly when pile driving is used to fix foundations to the seabed [53]-[55]. Once in operation, however, marine mammals can be expected to return and utilize the area. The activity of harbor porpoise (Phocoena phocoena) in wind farms has been studied in several monitoring programs, with somewhat inconsistent results. A long term study at the Danish wind farm "Nysted" in the Great Belt indicated a significant decline in porpoise activity that lasted years after the wind farm had been established [56]. On the contrary, the porpoise activity in the adjacent wind farm "Rødsand II" did not change when the wind farm was installed [57]. This inconsistency is difficult to reconcile as both wind farms are based on gravity foundations that did not involve disturbing pile driving operations. The pre-construction monitoring period at "Nysted" was very short and it is possible that the apparent decline was an artefact of natural variation. Monitoring results from another four offshore wind farms in the North Sea and Baltic Sea indicated that porpoise activity returns to normal levels once the construction work has been completed [58]-[61]. Moreover, monitoring at the Dutch "Egmond aan Zee" wind farm in the North Sea showed increased porpoise activity in the operating wind farm compared to before installation [62]. The authors attributed this positive change in porpoise activity to either reduced disturbance from shipping or to increased food availability in the wind farm. The latter hypothesis of wind farms as feeding grounds has been shown for harbor seal (Phoca vitulina), with seals methodically swimming from turbine to turbine in search for prey by the foundations [49]. While this wind farm feeding behavior is advantageous for the seal it may obviously be disadvantageous for its prey. 
Evidently, some marine mammals are attracted to, and spend time in, offshore wind farms. As long as gillnet fishing is reduced or prohibited these animals are simultaneously exposed to less risk of getting snared in nets. From a conservation point of view this is probably the most important benefit of wind farms on marine mammals, as these animals, harbor porpoises in particular, are subjected to substantial losses as bycatch in fishing nets [63] [64]. But to secure this advantage gillnet fishing has to be restricted in the wind farm, which is not always the case. In contrast to trawl fishing it is possible, and sometimes allowed, to use gillnets in wind farms (e.g. "Lillgrund" in Öresund strait).

\subsection{Seabirds at Offshore Wind Farms}

Impacts of offshore wind power on birds can be categorized into collisions, habitat loss, habitat gain, and migration barriers. Wind power rotor blades sweep the air at altitudes from tens of meters up to two hundred meters. This fast moving obstacle can be difficult to avoid for birds under conditions of low visibility [65]-[67]. Onshore wind power kills, on average, two birds per turbine a year while the numbers are less known at sea [68]. However, available data indicate that losses at offshore locations are lower than on land [69]. The variation is large both on land and offshore and most losses occur at the same locations [68].

Wind farms can also have a repelling effect on seabirds including divers and scooters. If birds are repelled from a wind farm that is located in a feeding or wintering ground, this can be considered a loss of habitat [65] [70]. Such avoidance and habitat loss have been observed in the German North Sea wind farm "Alpha Ventus" [71], although no population-level effects have yet been established [72]. Among affected species are loons (Gavia spp.), kittiwake (Rissa spp.) and northern gannet (Morus bassanus). Similar long-term avoidance of divers have been reported from the Danish "Horns rev" wind farm in North Sea [69]. In the Baltic Sea, the projected wind farm "Finngrunden" at an offshore bank important to long-tailed duck (Clangula hyemalis) was eventually rejected much due to the risk of significant seabird habitat loss. A similar debate is ongoing regarding another projected offshore wind farm in the southern Baltic Sea (i.e. "Södra Midsjöbanken"). As has been argued in this case, it remains possible that seabird habitat loss diminishes as wind turbines grow in size. With 1 $\mathrm{km}$ between turbines, as in projected wind farms, seabirds may be able to avoid individual turbines without being removed from the area.

Some seabird species also take advantage of the offshore turbines, using them as resting sites during offshore foraging [65]. This has been observed for different species of gulls (Laridae), terns (Sternidae) and cormorants (Phalacrocorax spp.) [73]. This habitat gain is well known from birds resting and foraging at offshore oil platforms [74]. In addition to improved foraging and resting, the attraction also implies an increased risk of exposure for birds flying at rotor blade height [65] [74].

\subsection{Migrating Birds at Offshore Wind Farms}

Wind farms can become partial barriers for migrating birds that avoid and adjust their preferred route to encircle the obstacle. This has been shown for many species of migrating birds both at "Utgrunden" wind farm in the Baltic Sea and at Danish wind farms in the Great Belt and in the North Sea [69] [75]. In these studies, the vast majority of birds took a longer route, extending their flight with up to a few kilometers (longer detours during daytime than during night). At the "Alpha Ventus" wind farm, however, most migrating birds flew across the wind farm and it was concluded that there is no significant barrier effect [72]. At the "Alpha Ventus" migrating birds typically flew below the rotors; in other studies migrating birds entering the wind farms have tended to fly in a straight line between turbine rows [69].

In conclusion, impacts on migrating birds vary among species and locations. While single wind farms seem to have little effect on large-scale migration, cumulative effects may become important if wind power expands without consideration of migration routes [76]. With regards to indirect effects it is hypothetically possible that diving birds that forage on offshore banks would benefit from offshore wind farm establishment due to reduced risk of bird bycatch in gillnets. However, this possibility of increased survival due to fishing reductions remains speculative.

\section{Implications for Conservation}

From the previous sections we conclude that operational offshore wind farms, in broad terms, have positive im- 
pacts on seabed habitats and benthos, epifouling benthos, fish, seals and possibly porpoises. Impacts on seabirds seem mostly negative or neutral but some species also benefit from utilizing the turbine structures. These findings, summarized in Table 1, have implications for marine conservation.

\subsection{Direct Benefits for Conservation-Wind Farms Functioning as Reefs}

Under water the most striking effect of wind farms is the introduction of hard substrate and the associated colonization and attraction of fauna (the "reef effect") [77]. This kind of habitat enhancement and increased biodiversity in areas of hard bottom scarcity is often regarded as positive, which is illustrated by the common practice of installing artificial reefs for conservation purposes in parts of the world, including in Europe [78]. The artificial reefs provide space for settlement, shelter, foraging and for some species recruitment [38] [79] [80]. While this is not necessarily a means of effective conservation it may be a way of strengthening affected populations. In some cases artificial reefs have been created specifically for conservation purposes [81]. In other cases manmade structures, such as oil platforms, have been shown to improve biodiversity and benefit endangered species with time, such as the threatened cold-water coral species $L$. pertusa [82].

With regard to offshore wind farms, the potential for the reef effect to work in direct favor of conservation may be limited to certain sessile species and mobile fauna with very small home-ranges (e.g. gobiid fish, molluscs and anthozoans). These organisms may spend a long time, or several generations, at single turbines where they benefit from space, food and shelter but will also be exposed to turbine noise and potentially increased predation pressure. For attracted species that move over large areas (e.g. seals, gadoid fish, and migrating crustaceans) the artificial reefs may only provide temporary advantages. Importantly though, the introduction of hard substrate per se can be considered a means of habitat conservation, or replenishment, in regions where vast areas of hard bottom substrates (stones, rocks, biogenic reefs) have disappeared due to bottom trawling, such as eastern Kattegat and south-eastern North Sea [28].

\subsection{Indirect Benefits for Conservation-Wind Farms Functioning as Marine Reserves}

The potential restriction of fishing is likely the most potent benefit of offshore wind farms from a conservation point of view. As previously mentioned, trawling is always prohibited for safety reasons. At locations previously exposed to bottom trawl fisheries this means an elimination of disturbance for fish, benthos and benthic habitats. At shallow locations fishing is typically carried out through gillnet fishing rather than trawling. If this means of fishing is also prohibited or reduced positive impacts will be even larger [13]. By reducing gillnet fishing not only fish but also marine mammals and potentially diving birds are relieved from catch and bycatch.

As with ordinary MPAs and reserves the effectiveness of wind farms in protecting wildlife and replenishing populations outside the area is highly dependent on wind farm size, location and the species under consideration. The matter of size has been much debated within conservation biology. One consideration of size is that small conservation areas are easier to implement compared to large areas which can be difficult to enforce and safeguard [5]. This concern is, however, not as relevant in the case of offshore wind farms as these are constructed

Table 1. The general impacts of an operating wind farm on categories of ecosystem components. Blanks indicate "not applicable”.

\begin{tabular}{|c|c|c|c|c|}
\hline \multirow{2}{*}{ Category } & \multicolumn{3}{|c|}{ Impact } & \multirow[b]{2}{*}{ Indirect benefits } \\
\hline & Biodiversity & Abundance & Negative impacts & \\
\hline $\begin{array}{l}\text { Benthic habitats } \\
\text { and benthos }\end{array}$ & Increase & $\begin{array}{l}\text { Increase of hard substrate } \\
\text { habitats }\end{array}$ & $\begin{array}{l}\text { Partial loss of soft sediment } \\
\text { habitats }\end{array}$ & $\begin{array}{l}\text { Habitats not damaged by } \\
\text { trawling }\end{array}$ \\
\hline $\begin{array}{l}\text { Epifouling } \\
\text { benthos }\end{array}$ & Increase & Increase & $\begin{array}{l}\text { Potential introduction of } \\
\text { invasive species }\end{array}$ & - \\
\hline Fish & Increase & Increase & No indications & Reduced fishing pressure \\
\hline Porpoises & - & Not established & Not established & Reduced bycatch risk \\
\hline Seals & - & Increase & No indications & Reduced bycatch risk \\
\hline Seabirds & Decrease & $\begin{array}{l}\text { Decrease of some species, } \\
\text { increase of others }\end{array}$ & $\begin{array}{l}\text { Potential habitat loss and } \\
\text { collision risk }\end{array}$ & Not established \\
\hline Migrating birds & - & - & Possible barrier effect & - \\
\hline
\end{tabular}


for other reasons than conservation. A more relevant consideration of size is the conservation effectiveness for mobile species with large home ranges, where ecological connectivity is of critical importance [83]. As discussed above, small conservation areas can be important in the protection of sessile and stationary species [5]. But migrating and large species move over vast areas and conservation areas that are too small may be of little value. In order to strongly support recruitment the size and location of the protected area should match with both spawning and larval dispersal patterns [84]. Nevertheless, all time spent in protected areas where mortality rates are reduced to some extent contributes to the strengthening of the concerned population.

Importantly, offshore wind farms have grown in size over time. Most monitoring data are sampled from arrays of up to 50 turbines, each separated by a couple of hundred meters. Offshore wind farms being planned today typically contain hundreds of turbines separated by up to a kilometer. Modern turbines are also larger which means larger towers, foundations and score protection. Given this trend, future wind farms can be expected to be sparser and cover larger areas than existing arrays. This enhances the spatial requirements and has implications for the potential for wind farms to function in favor for conservation.

Recently projected wind farms each cover $100-1000 \mathrm{~km}^{2}$ of seabed [9]. In 2011, the average size of existing MPAs was $113 \mathrm{~km}^{2}$ in the North Sea and $44 \mathrm{~km}^{2}$ in the Baltic Sea, although a few of the MPAs are actually in the order of $1000 \mathrm{~km}^{2}$ [3]. Notably, most of the existing MPAs only offer a partial protection since many different human activities are allowed [3]. Commercial fishing is a major pressure in many European Natura 2000 MPAs [3] [85]. According to the European Environment Agency only 1\% of European MPAs can be considered strict marine reserves with extensive limits to human disturbance [3]. This means that the size of modern offshore wind farms are in the same order of magnitude as large existing MPAs and that the protection towards fishing is likely to be as strict or stricter in a wind farm than in ordinary MPAs.

Indirectly, offshore wind farms can thus be at least as effective as existing MPAs in terms of creating refuges for benthic habitats, benthos, fish and marine mammals. In areas where trawling otherwise occurs, the installation of wind power would have major conservation benefits and wind farms that redirect ship traffic also reduces potential sources of pollution and underwater noise (commercial ships are far louder than operating wind turbines [86]). These conservation benefits are likely to be enhanced if the location makes it a part of a marine reserve patchwork that strengthens marine connectivity, or if it covers an area of particular importance for a concerned population, such as spawning, nursery or feeding ground.

More specifically, it is essential to understand species-specific home range properties as well as source-sink relationships in order to in detail evaluate the effects of a wind farm on conservation efficiency. The actual level of protection from a wind farm may be strongly linked to the configuration of the landscape mosaic as well as interacting processes operating at various spatiotemporal scales.

\subsection{Awareness and Negative Impacts}

The development of offshore wind farms in ecologically valuable areas obviously requires strong precautions during the potentially harmful phases: prospecting, installation and decommissioning. For instance, if acoustic disturbance from seismic operations, pile-driving or decommissioning explosions kill or significantly disturb endangered animals during their spawning or nursing periods this damage may overshadow any subsequent conservation benefits [11]. There is also a need for thorough consideration of species that can be negatively affected by operational wind farms, such as many species of seabirds. Lastly, it should be noted that it has been argued that artificial structures can also serve as vectors for invasive species, previously restricted back by lack of habitat [12] [87] [88]. Given these potential impacts all locations are not favorable for offshore wind power from a conservation point of view.

\section{Spatial Planning and Compatibility among Sectors}

Marine space is demanded by multiple sectors and conservation efforts must take into consideration social and economic values of the seas in order to create sustainable management options that ensure compliance [89]. Such management requires evaluation of trade-offs and here MSP has a key role. For instance, for spatial reasons offshore wind power is not compatible with trawl fishing or shipping. Both fisheries and transport are two traditional and powerful sectors. As the energy sector negotiates for space in crowded seas the understanding of offshore wind farms as compatible (tolerable) and even synergistic (enhancing) with conservation interests, as indicated in this review, can be of high importance for MSP. The basic conditions for offshore wind power to be 
considered a means of conservation in the context of MSP are i) that fishing is restricted in the wind farm, ii) that mitigation measures are undertaken during prospecting, installation and decommissioning, and iii) that negative impacts on seabirds are considered.

\section{Conclusions}

As shown in this review, there is evidence that operational offshore wind farms generate increased biodiversity and abundance for many taxa. Moreover, the indirect impacts of reduced fishing inside the wind farm can be highly valuable from a conservation point of view. Benthic habitats and benthos, epifouling benthos, seals and many species of fish are positively affected. Porpoises are likely to benefit as long as gillnet fishing is prohibited. Several species of seabirds, however, are negatively affected as they tend to avoid the area and therefore suffer a loss of habitat. These negative impacts on birds may potentially ease as modern wind farms grow larger with an increased distance between each turbine.

With regards to marine invertebrates, fish and mammals, the many monitoring programs at existing wind farms support that wind farms and marine conservation interests are compatible, or even synergistic, depending on location. Wind farms located in favor of marine connectivity or in areas of importance for ecological functions such as reproduction can thus be a powerful means of conservation. This potential of wind power development to contribute to conservation efforts is evident and should not be overlooked. These findings may be of interest among conservationists, planners and policy makers in the North Sea and the Baltic Sea where both offshore wind power and marine spatial planning are developing. Nonetheless, negative impacts of offshore wind power, associated with prospecting, installation and decommissioning should be mitigated as well as the potential exclusion of seabirds from important feeding and wintering grounds.

\section{References}

[1] Belgrano, A. and Fowler, C.W. (2013) How Fisheries Affect Evolution. Science, 342, 1176-1177. http://dx.doi.org/10.1126/science.1245490

[2] Halpern, B.S., Walbridge, S., Selkoe, K.A., Kappel, C.V., Micheli, F., et al. (2008) A Global Map of Human Impact on Marine Ecosystems. Science, 319, 948-952. http://dx.doi.org/10.1126/science.1149345

[3] EEA (2012) Protected Areas in Europe-An Overview. European Environment Agency, Copenhagen, 136 p.

[4] European Commission (1992) Council Directive 92/43/EEC on the Conservation of Natural Habitats and of Wild Fauna and Flora. Official Journal of the European Union, 568-583. http://eur-lex.europa.eu/legal-content/EN/TXT/PDF/?uri=CELEX:01992L0043-20070101\&from=EN

[5] Toonen, R.J., Wilhelm, T.A., Maxwell, S.M., Wagner, D., Bowen, B.W., et al. (2013) One Size Does Not Fit All: The Emerging Frontier in Large-Scale Marine Conservation. Marine Pollution Bulletin, 77, 7-10. http://dx.doi.org/10.1016/j.marpolbul.2013.10.039

[6] European Commission (2014) Directive 2014/89/EU of the European Parliament and of the Council: Establishing a Framework for Maritime Spatial Planning. Official Journal of the European Union, 135-145. http://eur-lex.europa.eu/legal-content/EN/TXT/?qid=1437144467139\&uri=CELEX:32014L0089

[7] Ehler, C. and Douvere, F. (2009) Marine Spatial Planning a Step-by-Step Approach toward Ecosystem-Based Management. Intergovernmental Oceanographic Commission, Paris.

[8] European Commission (2008) Directive 2008/56/EC of the European Parliament and of the Council: Establishing a Framework for Community Action in the Field of Marine Environmental Policy (Marine Strategy Framework Directive). Official Journal of the European Union. http://eur-lex.europa.eu/LexUriServ/LexUriServ.do?uri=OJ:L:2008:164:0019:0040:EN:PDF

[9] 4C Offshore Database (2014) Global Offshore Wind Farms Database. http://www.4coffshore.com/windfarms/default.aspx

[10] Hammar, L. (2014) Power from the Brave New Ocean-Marine Renewable Energy and Ecological Risks. http://publications.lib.chalmers.se/publication/196091-power-from-the-brave-new-ocean-marine-renewable-energy-and -ecological-risks

[11] Hammar, L., Wikström, A. and Molander, S. (2014) Assessing Ecological Risks of Offshore Wind Power on Kattegat Cod. Renewable Energy, 66, 414-424. http://dx.doi.org/10.1016/j.renene.2013.12.024

[12] Bergström, L., Kautsky, L., Malm, T., Rosenberg, R., Wahlberg, M., et al. (2014) Effects of Offshore Wind Farms on Marine Wildlife-A Generalized Impact Assessment. Environmental Research Letters, 9, Article ID: 034012. http://dx.doi.org/10.1088/1748-9326/9/3/034012 
[13] Reubens, J.T., Degraer, S. and Vincx, M. (2014) The Ecology of Benthopelagic Fishes at Offshore Wind Farms: A Synthesis of 4 Years of Research. Hydrobiologia, 727, 121-136. http://dx.doi.org/10.1007/s10750-013-1793-1

[14] Halpern, B.S. (2003) The Impact of Marine Reserves: Do Reserves Work and Does Reserve Size Matter? Ecological Applications, 13, 117-137. http://dx.doi.org/10.1890/1051-0761(2003)013[0117:TIOMRD]2.0.CO;2

[15] Bohnsack, J. (1990) The Potential of Marine Fishery Reserves for Reef Fish Management in the US Southern Atlantic. NOAA Technical Memorandum, NMFS-SEFC-261, 1-40.

[16] McClanahan, T.R. and Mangi, S. (2000) Spillover of Exploitable Fishes from a Marine Park and Its Effect on the Adjacent Fishery. Ecological Applications, 10, 1792-1805. http://dx.doi.org/10.1890/1051-0761(2000)010[1792:SOEFFA]2.0.CO;2

[17] Hammar, L., Andersson, S. and Rosenberg, R. (2008) Adapting Offshore Wind Power Foundations to Local Environment. Vindval, The Swedish Environmental Protection Agency, Bromma, 87 p.

[18] Schläppy, M.-L., Šaškov, A. and Dahlgren, T.G. (2014) Impact Hypothesis for Offshore Wind Farms: Explanatory Models for Species Distribution at Extremely Exposed Rocky Areas. Continental Shelf Research, 83, 14-23. http://dx.doi.org/10.1016/j.csr.2013.11.018

[19] Miller, R.G., Hutchison, Z.L., Macleod, A.K., Burrows, M.T., Cook, E.J., et al. (2013) Marine Renewable Energy Development: Assessing the Benthic Footprint at Multiple Scales. Frontiers in Ecology and the Environment, 11, $433-440$. http://dx.doi.org/10.1890/120089

[20] Lynge, H. (2004) Middelgrunden: Biologisk undersøgelse ved vindmølleparken på Middelgrunden ved København, efterår 2003. Miljø- og Energi as, Roskilde, 46 p.

[21] Toxicon, A.B. (2006) Baslinjeundersökning till kontrollprogram för miljöövervakning vid byggandet av vindkraftsparken på Lillgrund. Landskrona, $14 \mathrm{p}$.

[22] Brabant, R., Degraer, S. and Rumes, B. (2012) Offshore Wind Energy Development in the Belgian Part of the North Sea \& Anticipated Impacts: An Update. In: Brabant, R., Degraer, S. and Rumes, B., Eds., Offshore Wind Farms in the Belgian Part of the North Sea: Heading for an Understanding of Environmental Impacts, Royal Belgian Institute of Natural Sciences, Brussels, 9-16.

[23] Degraer, S., Brabant, R. and Rumes, B., Eds. (2012) Offshore Wind Farms in the Belgian Part of the North Sea: Heading for an Understanding of Environmental Impacts. Royal Belgian Institute of Natural Sciences, Brussels, 155 p.

[24] Buhl-Mortensen, L., Buhl-Mortensen, P., Dolan, M.F.J., Dannheim, J., Bellec, V., et al. (2012) Habitat Complexity and Bottom Fauna Composition at Different Scales on the Continental Shelf and Slope of Northern Norway. Hydrobiologia, 685, 191-219. http://dx.doi.org/10.1007/s10750-011-0988-6

[25] Thurstan, R.H., Brockington, S. and Roberts, C.M. (2010) The Effects of 118 Years of Industrial Fishing on UK Bottom Trawl Fisheries. Nature Communications, 1, 1-6. http://dx.doi.org/10.1038/ncomms1013

[26] Turner, S.J., Thrush, S.F., Hewitt, J.E., Cummings, V.J. and Funnell, G. (1999) Fishing Impacts and the Degradation or Loss of Habitat Structure. Fisheries Management and Ecology, 6, 401-420. http://dx.doi.org/10.1046/j.1365-2400.1999.00167.x

[27] Bergman, M.J.N. and Hup, M. (1992) Direct Effects of Beamtrawling on Macrofauna in a Sandy Sediment in the Southern North Sea. ICES Journal of Marine Science: Journal du Conseil, 49, 5-11. http://dx.doi.org/10.1093/icesjms/49.1.5

[28] Roberts, C. (2010) The Unnatural History of the Sea. Island Press, Washington DC, 456 p.

[29] ArtDatabanken (2015) Rödlistade arter i Sverige 2015. ArtDatabanken SLU, Uppsala, 221 p.

[30] Piet, G.J., Rijnsdorp, A.D., Bergman, M.J.N., van Santbrink, J.W., Craeymeersch, J., et al. (2000) A Quantitative Evaluation of the Impact of Beam Trawling on Benthic Fauna in the Southern North Sea. ICES Journal of Marine Science: Journal du Conseil, 57, 1332-1339. http://dx.doi.org/10.1006/jmsc.2000.0915

[31] Floderus, S. and Pihl, L. (1990) Resuspension in the Kattegat: Impact of Variation in Wind Climate and Fishery. Estuarine, Coastal and Shelf Science, 31, 487-498. http://dx.doi.org/10.1016/0272-7714(90)90039-T

[32] Esteban, M.D., Diez, J.J., López, J.S. and Negro, V. (2011) Why Offshore Wind Energy? Renewable Energy, 36, 444450. http://dx.doi.org/10.1016/j.renene.2010.07.009

[33] GlobalData (2013) Offshore Wind Power-Global Market Size, Average Installation Price, Regulations, Market Share and Key Country Analysis to 2020. GlobalData, London, 140 p.

[34] Kaiser, M.J., Clarke, K.R., Hinz, H., Austen, M.C.V., Somerfield, P.J., et al. (2006) Global Analysis of Response and Recovery of Benthic Biota to Fishing. Marine Ecology Progress Series, 311, 1-14. http://dx.doi.org/10.3354/meps311001

[35] Wilhelmsson, D. and Malm, T. (2008) Fouling Assemblages on Offshore Wind Power Plants and Adjacent Substrata. Estuarine, Coastal and Shelf Science, 79, 459-466. http://dx.doi.org/10.1016/j.ecss.2008.04.020 
[36] Andersson, M.H. and Öhman, M.C. (2010) Fish and Sessile Assemblages Associated with Wind-Turbine Constructions in the Baltic Sea. Marine and Freshwater Research, 61, 642-650. http://dx.doi.org/10.1071/MF09117

[37] Andersson, M., Berggren, M., Wilhelmsson, D. and Öhman, M. (2009) Epibenthic Colonization of Concrete and Steel Pilings in a Cold-Temperate Embayment: A Field Experiment. Helgoland Marine Research, 63, 249-260. http://dx.doi.org/10.1007/s10152-009-0156-9

[38] Wilhelmsson, D., Malm, T. and Öhman, M.C. (2006) The Influence of Offshore Windpower on Demersal Fish. ICES Journal of Marine Science: Journal du Conseil, 63, 775-784. http://dx.doi.org/10.1016/j.icesjms.2006.02.001

[39] Lindeboom, H.J., Kouwenhoven, H.J., Bergman, M.J.N., Bouma, S., Brasseur, S., et al. (2011) Short-Term Ecological Effects of an Offshore Wind Farm in the Dutch Coastal Zone: A Compilation. Environmental Research Letters, 6, Article ID: 035101. http://dx.doi.org/10.1088/1748-9326/6/3/035101

[40] Krone, K. and Krägefsky, S. (2013) Effects of Offshore Wind Turbine Foundations on Mobile Demersal Megafauna and Pelagic Fish—Research at the Offshore Wind Farm Alpha Ventus. Preliminary Agenda, 30-31 October 2013, Berlin.

[41] Bergmark, P. and Jørgensen, D. (2014) Lophelia pertusa Conservation in the North Sea Using Obsolete Offshore Structures as Artificial Reefs. Marine Ecology Progress Series, 516, 275-280. http://dx.doi.org/10.3354/meps10997

[42] OSPAR Commission (2009) Background Document for Lophelia pertusa Reefs. OSPAR Commission Biodiversity Series, London, $32 \mathrm{p}$.

[43] Bergström, L., Sundqvist, F. and Bergström, U. (2013) Effects of an Offshore Wind Farm on Temporal and Spatial Patterns in the Demersal Fish Community. Marine Ecology Progress Series, 485, 199-210. http://dx.doi.org/10.3354/meps10344

[44] Reubens, J., Degraer, S. and Vincx, M. (2011) Chapter 5: Spatial and Temporal Movements of Cod (Gadus morhua) in a Wind Farm in the Belgian Part of the North Sea Using Acoustic Telemetry, a VPS Study. In: Degraer, S., Brabant, R. and Runes, B., Eds., Offshore Wind Farms in the Belgian Part of the North Sea: Selected Findings from the Baseline and Targeted Monitoring, Royal Belgian Institute of Natural Sciences, Brussels, 39-46.

[45] Winter, H.V., Aarts, G. and Van Keeken, O.A. (2010) Residence Time and Behaviour of Sole and Cod in the Offshore Wind Farm Egmond aan Zee (OWEZ). IMARES, Wageningen.

[46] Lindeboom, H., Degraer, S., Dannheim, J., Gill, A. and Wilhelmsson, D. (2015) Offshore Wind Park Monitoring Programmes, Lessons Learned and Recommendations for the Future. Hydrobiologia, 756, 169-180. http://dx.doi.org/10.1007/s10750-015-2267-4

[47] Simpson, S.D., Purser, J. and Radford, A.N. (2015) Anthropogenic Noise Compromises Antipredator Behaviour in European Eels. Global Change Biology, 21, 586-593. http://dx.doi.org/10.1111/gcb.12685

[48] Reubens, J.T., Vandendriessche, S., Zenner, A.N., Degraer, S. and Vincx, M. (2013) Offshore Wind Farms as Productive Sites or Ecological Traps for Gadoid Fishes?-Impact on Growth, Condition Index and Diet Composition. Marine Environmental Research, 90, 66-74. http://dx.doi.org/10.1016/j.marenvres.2013.05.013

[49] Russell, D.J.F., Brasseur, S.M.J.M., Thompson, D., Hastie, G.D., Janik, V.M., et al. (2014) Marine Mammals Trace Anthropogenic Structures at Sea. Current Biology, 24, R638-R639. http://dx.doi.org/10.1016/j.cub.2014.06.033

[50] Stenberg, C., Støttrup, J., van Deurs, M., Berg, C., Dinesen, G., et al. (2015) Long-Term Effects of an Offshore Wind Farm in the North Sea on Fish Communities. Marine Ecology Progress Series, 528, 257-265. http://dx.doi.org/10.3354/meps11261

[51] Jackson, J.B.C. (2008) Ecological Extinction and Evolution in the Brave New Ocean. Proceedings of the National Academy of Sciences, 105, 11458-11465. http://dx.doi.org/10.1073/pnas.0802812105

[52] Pauly, D. (1995) Anecdotes and the Shifting Baseline Syndrome of Fisheries. Trends in Ecology \& Evolution, 10, 430. http://dx.doi.org/10.1016/S0169-5347(00)89171-5

[53] Madsen, P.T., Wahlberg, M., Tougaard, J., Lucke, K. and Tyack, P. (2006) Wind Turbine Underwater Noise and Marine Mammals: Implications of Current Knowledge and Data Needs. Marine Ecology Progress Series, 309, $279-295$. http://dx.doi.org/10.3354/meps309279

[54] Tougaard, J., Carstensen, J., Teilmann, J., Skov, H. and Rasmussen, P. (2009) Pile Driving Zone of Responsiveness Extends beyond $20 \mathrm{~km}$ for Harbor Porpoises (Phocoena phocoena L.). The Journal of the Acoustical Society of America, 126, 11-14. http://dx.doi.org/10.1121/1.3132523

[55] Bailey, H., Senior, B., Simmons, D., Rusin, J., Picken, G., et al. (2010) Assessing Underwater Noise Levels during Pile-Driving at an Offshore Windfarm and Its Potential Effects on Marine Mammals. Marine Pollution Bulletin, 60, 888-897. http://dx.doi.org/10.1016/j.marpolbul.2010.01.003

[56] Teilmann, J. and Carstensen, J. (2012) Negative Long Term Effects on Harbour Porpoises from a Large Scale Offshore Wind Farm in the Baltic_Evidence of Slow Recovery. Environmental Research Letters, 7, Article ID: 045101. http://dx.doi.org/10.1088/1748-9326/7/4/045101 
[57] Teilmann, J., Tougaard, J. and Carstensen, J. (2012) Effects on Harbour Porpoises from Rødsand 2 Offshore Wind Farm. Danish Centre for Environment and Energy, Aarhus.

[58] Tougaard, J. and Carstensen, J. (2011) Porpoises North of Sprogö before, during and after Construction of an Offshore Wind Farm. National Environmental Research Institute, Roskilde, 45 p.

[59] Braasch, A., Joost, M. and Ketzer, C. (2013) Responses of Harbour Porpoises to Pile Driving on a Temporal and Spatial Scale. Stockholm.

[60] Teilmann, J., Tougaard, J., Carstensen, J., Dietz, R. and Tougaard, S. (2006) Marine Mammals—Seals and Porpoises React Differently. In: Kjaer, J., Kyed Larsen, J., Boesen, C., Hassing Corlin, H., Andersen, S., et al., Eds., Danish Offshore Wind-Key Environmental Issues. www.ens.dk/offshorewind

[61] Canning, S., Lye, G., Givens, L. and Pendlebury, C. (2013) Analysis of Marine Ecology Monitoring Plan Data from the Robin Rigg Offshore Wind Farm, Scotland (Operational Year 2). Natural Power Consultants, Dalry.

[62] Scheidat, M., Tougaard, J., Brasseur, S., Carstensen, J., van Polanen Petel, T., et al. (2011) Harbour Porpoises (Phocoena phocoena) and Wind Farms: A Case Study in the Dutch North Sea. Environmental Research Letters, 6, Article ID: 025102. http://dx.doi.org/10.1088/1748-9326/6/2/025102

[63] Lewison, R., Crowder, L., Read, A. and Freeman, S. (2004) Understanding Impacts of Fisheries Bycatch on Marine Megafauna. Trends in Ecology \& Evolution, 19, 598-604. http://dx.doi.org/10.1016/j.tree.2004.09.004

[64] Vinther, M. and Larsen, F. (2004) Updated Estimates of Harbour Porpoise (Phocoena phocoena) Bycatch in the Danish North Sea Bottom-Set Gillnet Fishery. Journal of Cetacean Research and Management, 6, 19-24.

[65] Grecian, W.J., Inger, R., Attrill, M.J., Bearhop, S., Godley, B.J., et al. (2010) Potential Impacts of Wave-Powered Marine Renewable Energy Installations on Marine Birds. Ibis, 152, 683-697. http://dx.doi.org/10.1111/j.1474-919X.2010.01048.x

[66] NWCC, National Wind Coordinating Collaborative (2010) Wind Turbine Interactions with Birds, Bats, and Their Habitats: A Summary of Research Results and Priority Questions. http://nationalwind.org/research/publications/birds-and-bats-fact-sheet/

[67] Desholm, M. and Kahlert, J. (2005) Avian Collision Risk at an Offshore Wind Farm. Biology Letters, 1, $296-298$. http://dx.doi.org/10.1098/rsbl.2005.0336

[68] Rydell, J., Engström, H., Hedenström, A., Kyed Larsen, J., Pettersson, J., et al. (2011) Vindkraftens påverkan på fåglar och fladdermöss-syntesrapport. Naturvårdsverket, Bromma.

[69] Petersen, I., Christensen, T., Kahlert, J., Desholm, M. and Fox, A. (2006) Final Results of Bird Studies at the Offshore Wind Farms at Nysted and Horns Rev. Institute NER, Editor, Roskilde.

[70] Furness, R.W., Wade, H.M. and Masden, E.A. (2013) Assessing Vulnerability of Marine Bird Populations to Offshore Wind Farms. Journal of Environmental Management, 119, 56-66. http://dx.doi.org/10.1016/j.jenvman.2013.01.025

[71] Garthe, S., Mendel, B., Kotzerka, J. and Sommerfield, J. (2013) Effects of Alpha Ventus on Distribution Patterns, Behavior and Flight Heights of Seabirds. Preliminary Agenda, 30-31 October 2013, Berlin.

[72] Mendel, B., Kotzerka, J., Sommerfield, J., Schwemmer, H., Sonntag, N., et al. (2014) Effects of the Alpha Ventus Offshore Test Site on Distribution Patterns, Behavior and Flight Heights of Seabirds. In: Beiersdorf, A. and Radecke, A., Eds., Ecological Research at the Offshore Windfarm Alpha Ventus-Challenges, Results and Perspectives, Springer Spektrum, Berlin, 95-110. http://dx.doi.org/10.1007/978-3-658-02462-8_11

[73] Ludeke, J. (2015) A Review of 10 Years of Research of Offshore Wind Farms in Germany: The State of Knowledge of Ecological Impacts. Proceedings of the WSEAS Conferences, Salerno, 27-29 June 2015, 25-37.

[74] Wiese, F.K., Montevecchi, W.A., Davoren, G.K., Huettmann, F., Diamond, A.W., et al. (2001) Seabirds at Risk around Offshore Oil Platforms in the North-West Atlantic. Marine Pollution Bulletin, 42, 1285-1290. http://dx.doi.org/10.1016/S0025-326X(01)00096-0

[75] Pettersson, J. (2005) Havsbaserade vindkraftverks inverkan på fågellivet i södra Kalmarssund. Energimyndigheten, Stockholm.

[76] Busch, M., Kannen, A., Garthe, S. and Jessopp, M. (2013) Consequences of a Cumulative Perspective on Marine Environmental Impacts: Offshore Wind Farming and Seabirds at North Sea Scale in Context of the EU Marine Strategy Framework Directive. Ocean \& Coastal Management, 71, 213-224. http://dx.doi.org/10.1016/j.ocecoaman.2012.10.016

[77] Langhamer, O. (2012) Artificial Reef Effect in Relation to Offshore Renewable Energy Conversion: State of the Art. The Scientific World Journal, 2012, 1-8. http://dx.doi.org/10.1100/2012/386713

[78] Jensen, A. (2002) Artificial Reefs of Europe: Perspective and Future. ICES Journal of Marine Science: Journal du Conseil, 59, S3-S13. http://dx.doi.org/10.1006/jmsc.2002.1303

[79] Pickering, H. and Whitmarsh, D. (1997) Artificial Reefs and Fisheries Exploitation: A Review of the "Attraction ver- 
sus Production” Debate, the Influence of Design and Its Significance for Policy. Fisheries Research, 31, 39-59. http://dx.doi.org/10.1016/S0165-7836(97)00019-2

[80] NOAA (2012) Office of National Marine Sanctuaries Science Review of Artificial Reefs. National Ocean and Atmospheric Administration, Silver Spring, 46 p.

[81] Pickering, H., Whitmarsh, D. and Jensen, A. (1999) Artificial Reefs as a Tool to Aid Rehabilitation of Coastal Ecosystems: Investigating the Potential. Marine Pollution Bulletin, 37, 505-514. http://dx.doi.org/10.1016/S0025-326X(98)00121-0

[82] Schroeder, D.M. and Love, M.S. (2004) Ecological and Political Issues Surrounding Decommissioning of Offshore Oil Facilities in the Southern California Bight. Ocean \& Coastal Management, 47, 21-48. http://dx.doi.org/10.1016/j.ocecoaman.2004.03.002

[83] Grober-Dunsmore, R., Pittman, S., Caldow, C., Kendall, M. and Frazer, T. (2009) A Landscape Ecology Approach for the Study of Ecological Connectivity across Tropical Marine Seascapes. In: Nagelkerken, I., Ed., Ecological Connectivity among Tropical Coastal Ecosystems, Springer, Dordrecht, 493-530. http://dx.doi.org/10.1007/978-90-481-2406-0_14

[84] Carr, M.H. and Hixon, M.A. (1997) Artificial Reefs: The Importance of Comparisons with Natural Reefs. Fisheries, 22, 28-33. http://dx.doi.org/10.1577/1548-8446(1997)022<0028:ARTIOC>2.0.CO;2

[85] Christiernsson, A., Michanek, G. and Nilsson, P. (2015) Marine Natura 2000 and Fishery-The Case of Sweden. Journal for European Environmental and Planning Law, 12, 22-49. http://dx.doi.org/10.1163/18760104-01201002

[86] Hildebrand, J.A. (2009) Anthropogenic and Natural Sources of Ambient Noise in the Ocean. Marine Ecology Progress Series, 395, 5-20. http://dx.doi.org/10.3354/meps08353

[87] Adams, T.P., Miller, R.G., Aleynik, D. and Burrows, M.T. (2014) Offshore Marine Renewable Energy Devices as Stepping Stones across Biogeographical Boundaries. Journal of Applied Ecology, 51, 330-338. http://dx.doi.org/10.1111/1365-2664.12207

[88] Glasby, T., Connell, S., Holloway, M. and Hewitt, C. (2007) Nonindigenous Biota on Artificial Structures: Could Habitat Creation Facilitate Biological Invasions? Marine Biology, 151, 887-895. http://dx.doi.org/10.1007/s00227-006-0552-5

[89] Mazor, T., Giakoumi, S., Kark, S. and Possingham, H.P. (2014) Large-Scale Conservation Planning in a Multinational Marine Environment: Cost Matters. Ecological Applications, 24, 1115-1130. http://dx.doi.org/10.1890/13-1249.1 